\title{
Relationships Between Chemical Defenses of Common Toad (Bufo bufo) Tadpoles and Bacterial Community Structure of their Natural Aquatic Habitat
}

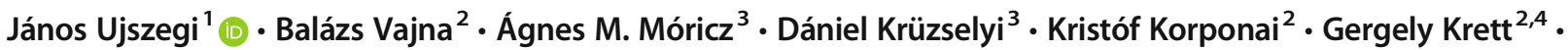 \\ Attila Hettyey ${ }^{1}$
}

Received: 24 September 2019 / Revised: 10 March 2020 / Accepted: 15 May 2020 / Published online: 28 May 2020

(C) The Author(s) 2020

\begin{abstract}
Many organisms synthesize secondary metabolites against natural enemies. However, to which environmental factors the production of these metabolites is adjusted to is poorly investigated in animals, especially so in vertebrates. Bufadienolides are steroidal compounds that are present in a wide range of plants and animals and, if present in large quantities, can provide protection against natural enemies, such as pathogens. In a correlative study involving 16 natural populations we investigated how variation in bufadienolide content of larval common toads (Bufo bufo) is associated with the bacterial community structure of their aquatic environment. We also evaluated pond size, macrovegetation cover, and the abundance of predators, conspecifics and other larval amphibians. We measured toxin content of tadpoles using HPLC-MS and determined the number of bufadienolide compounds (NBC) and the total quantity of bufadienolides (TBQ). AICc-based model selection revealed strong relationships of NBC and TBQ with bacterial community structure of the aquatic habitat as well as with the presence of conspecific tadpoles. The observed relationships may have arisen due to adaptation to local bacterial communities, phenotypic plasticity, differential biotransformation of toxin compounds by different bacterial communities, or a combination of these processes. Bacterial groups that contribute to among-population variation in toxin content remain to be pinpointed, but our study suggesting that toxin production may be influenced by the bacterial community of the environment represents an important step towards understanding the ecological and evolutionary processes leading to microbiota-mediated variation in skin toxin profiles of aquatic vertebrates.
\end{abstract}

Keywords Bufadienolide $\cdot$ Local adaptation $\cdot$ Toxin production $\cdot$ Bufo bufo $\cdot$ Pond microbiota

Electronic supplementary material The online version of this article (https://doi.org/10.1007/s10886-020-01184-4) contains supplementary material, which is available to authorized users.

János Ujszegi

ujszegi.janos@gmail.com

1 Lendület Evolutionary Ecology Research Group, Plant Protection Institute, Centre for Agricultural Research, Herman Ottó út 15, Budapest 1022, Hungary

2 Department of Microbiology, Eötvös Loránd University, Pázmány Péter sétány $1 / C$, Budapest 1117, Hungary

3 Department of Pathophysiology, Plant Protection Institute, Centre for Agricultural Research, Herman Ottó út 15, Budapest 1022, Hungary

4 Danube Research Institute, Centre for Ecological Research, Karolina út 29, Budapest 1113, Hungary

\section{Introduction}

Many organisms are capable of synthesizing secondary metabolites de novo, which can act as chemical defenses against predators, competitors and pathogens (Brodie 2009; Mebs 2001; Toledo and Jared 1995). Despite a growing body of information about the functions and ecological roles of defensive chemicals in plants and marine invertebrates, information regarding spatial and temporal variation in toxin production, and its relationships with environmental factors has remained limited in vertebrates (Hettyey et al. 2014).

The nature and magnitude of chemical defense generally depend on the relationship between the benefit of the defense and its costs (McCall and Fordyce 2010; Tollrian and Harvell 1999). Intraspecific variation in toxin production among populations can arise at least through three mechanisms: local adaptation, phenotypic plasticity and genetic drift. If local environmental changes are highly predictable, but differ 
among sites, different levels of constitutive defenses are expected. This results in local adaptation with fixed toxin levels: members of populations are highly toxic if encounter rates with natural enemies are high and less toxic if the threat posed by enemies is relatively low (Hague et al. 2016). In contrast, environments where ecologically important factors vary unpredictably favor the evolution of phenotypic plasticity, which is the ability of individual genotypes to produce different phenotypes in different environmental conditions (DeWitt and Scheiner 2004; Harvell 1990; West-Eberhard 1989). In case of genetic drift, spatial variation in toxin levels can appear among small, genetically isolated populations caused by random processes leading to changes in allele frequencies (Nei et al. 1975).

Steroidal bufadienolides are among the most studied groups of biologically active compounds constituting chemical defenses. They have been isolated from both plant and animal sources and are known to block membrane $\mathrm{Na}^{+} / \mathrm{K}^{+}$ATPases, making them cardiotoxic if present at sufficient quantities (Daly 1995; Krenn and Kopp 1998; Steyn and van Heerden 1998). Several toad species in the family Bufonidae are known to synthesize bufadienolides de novo in the serous glands of their skin already from early larval stages on (Hayes et al. 2009a; Ujszegi et al. 2017; Üveges et al. 2017). These skin-toxins may be effective against natural enemies including predators (Denton and Beebee 1991; Hantak et al. 2016; Kruse and Stone 1984; Peterson and Blaustein 1991; Shine 2010), competitors (Bókony et al. 2018) and potential pathogens (Barnhart et al. 2017; Cunha Filho et al. 2005; De Medeiros et al. 2019; Tempone et al. 2008). However, little is known about what evolutionary processes and environmental factors influence bufadienolide synthesis.

In a previous study on among-population variation in the toxin content of larval common toads (Bufo bufo) in natural habitats we observed that tadpole toxin content was related to the density of conspecifics and to pond permanence, but not to predator abundance (Bókony et al. 2016). However, in that study, microbial communities of the studied ponds were ignored. As demonstrated by Cunha Filho et al. (2005), bufadienolide compounds synthesized in the skin of Rhinella $(=$ Bufo) rubescens have potent antimicrobial activity against both Gram-positive and Gram-negative bacteria. Also, bufadienolides can inhibit the growth of Batrachochytrium dendrobatidis, a fungal pathogen associated with global amphibian declines (Barnhart et al. 2017). Although bufadienolides are present, defensive antimicrobial peptides (AMPs) are lacking from the skin of bufonids (Conlon 2011; König et al. 2015). This suggests that bufadienolides play an important role in skin-based immune-defense, and as such, may be highly responsive to changes in the microbial community present in their environment. Finally, it has been demonstrated that some microbes can biotransform bufadienolide compounds (Hayes et al. 2009b), which may in turn also contribute to among-population variation in toxin content.

We investigated whether the composition and quantity of defensive skin toxins in common toad (Bufo bufo) larvae may be influenced by the bacterial community present in the environment. To achieve this, we conducted a field survey in 16 natural habitats of the common toad. We related bufadienolide profiles of larval toads to bacterial community structure of their aquatic environment, while controlling for other, potentially influential biotic factors and abiotic pond parameters. We predicted to find a positive relationship between toxin content of tadpoles and the density of their competitors, as well as a strong influence of the bacterial community present in the aquatic environment. We chose to investigate the relationship between the microbial community of the aquatic environment and skin toxin content because it is the water surrounding anuran larvae that serves as the source of the microbiota colonizing their skin. At the same time, microbes present in the immediate environment can have a decisive influence on the skin-based immune-defense of amphibians, such as on the synthesis of AMP-s (Krynak et al. 2016). While it is the microbes that get into direct contact with individuals that matter for the immune-response, the microbial community present on the skin differs from the environmental pool (Rebollar et al. 2016; Walke et al. 2014) and is already selected by skinsecreted chemical defenses (Vartoukian et al. 2010).

\section{Materials and Methods}

Data collection. In late May and early June 2015, we visited 16 ponds in the Pilis-Visegrádi Mountains, Hungary, known to be common toad breeding sites (Vági et al. 2013). These ponds are located in deciduous forests between 200 and $570 \mathrm{~m}$ above sea level and are known to dry out every few years so that fishes are not present. Surface area ranged between 66 and $3699 \mathrm{~m}^{2}$, maximal water depth between 30 and more than $100 \mathrm{~cm}$ (Table 1; Electronic supplementary material 1). We estimated canopy cover and pond macrovegetation cover as percentage of pond surface in 5\% increments. Average water conductivity and $\mathrm{pH}$ were calculated from measurements taken on 5 randomly collected water samples per pond, measured by a portable electrochemistry meter (Consort C $6020 \mathrm{~T}$ ). The above pond parameters are related to the probability of desiccation and are important parameters that can influence both the development and physiological performance of tadpoles (McDiarmid and Altig 1999), but also the community structure of the aquatic microbiota (Krynak et al. 2015, 2016). We estimated the density of predators, as well as of conspecific and heterospecific tadpoles by performing $1 \mathrm{~m}$ long sweeps (ca. $0.4 \mathrm{~m}^{2}$ ) along the bottom of ponds with dip-nets, and subsequent counting of captured animals. We took 4-12 dip-net 
Table 1 Locations of sampling sites. Sample sizes and average developmental stages (according to Gosner 1960) are also shown. For habitat characteristics of sampling sites please see Electronic supplementary material

\begin{tabular}{|c|c|c|c|c|c|c|}
\hline $\begin{array}{l}\text { Pond } \\
\text { ID }\end{array}$ & Pond name & $\begin{array}{l}\text { Date of } \\
\text { visit }\end{array}$ & Latitude & Longitude & $\begin{array}{l}N \text { of tadpoles } \\
\text { per pond }\end{array}$ & $\begin{array}{l}\text { Mean } \\
\text { Gosner } \\
\text { stage }\end{array}$ \\
\hline 1 & Alsó-hosszúrét & 27.05 .2015 & 47.7155 & 19.0227 & 4 & 35 \\
\hline 2 & Bükkipuszta & 01.06 .2015 & 47.7013 & 18.9493 & 10 & 26.7 \\
\hline 3 & Felső-hosszúrét 1 & 08.06 .2015 & 47.7266 & 19.0158 & 10 & 27 \\
\hline 4 & Felső-hosszúrét 3 & 08.06 .2015 & 47.7268 & 19.0167 & 10 & 37.2 \\
\hline 5 & János-tó & 27.05 .2015 & 47.7143 & 19.0197 & 10 & 33.5 \\
\hline 6 & Mélymocsár & 03.06 .2015 & 47.7076 & 19.0401 & 3 & 27 \\
\hline 7 & Nagykovácsi-tó & 08.06 .2015 & 47.5764 & 18.8686 & 10 & 36.6 \\
\hline 8 & Paprét-középső & 03.06 .2015 & 47.7389 & 19.0118 & 5 & 27 \\
\hline 9 & Szárazfarkas-belső & 01.06 .2015 & 47.7345 & 18.8188 & 10 & 31.1 \\
\hline 10 & Szarvasszérü & 08.06 .2015 & 47.7294 & 19.0069 & 9 & 26.5 \\
\hline 11 & Szarvasszérü-megálló & 08.06 .2015 & 47.7299 & 19.0086 & 10 & 27.5 \\
\hline 12 & Sóstó & 04.06 .2015 & 47.7753 & 19.0042 & 10 & 34.6 \\
\hline 13 & Sóstó-zsombékos & 04.06 .2015 & 47.7748 & 19.0044 & 10 & 33.6 \\
\hline 14 & Vörös-dagonya & 01.06 .2015 & 47.7062 & 18.9227 & 10 & 36.1 \\
\hline 15 & Vértes-Észak & 03.06 .2015 & 47.7411 & 19.0439 & 10 & 33.7 \\
\hline 16 & Zánkó & 03.06 .2015 & 47.7392 & 19.0257 & 9 & 35 \\
\hline
\end{tabular}

samples depending on pond size, while taking care to represent microhabitats according to their share of pond area. Subsequently, for each pond we calculated the density of animal taxa as the average number of captured individuals across all dip-net samples. For the analysis of the bacterial communities of ponds, we collected $2 \mathrm{~L}$ composite water samples into autoclave-sterilized glass bottles from 10 locations within each pond where tadpoles were present (from water depths ranging between 10 and $45 \mathrm{~cm}$ ). Water samples were transported on ice to the Department of Microbiology, Eötvös Loránd University, Budapest, Hungary, and stored at $4{ }^{\circ} \mathrm{C}$ until further analysis.

Mean developmental stage (Gosner, 1960) of collected toad tadpoles varied among ponds between $26 \pm 1$ and 37.2 \pm 1.2 (mean $\pm \mathrm{SD}$ ). Common toad tadpoles are known to produce toxins de novo (Üveges et al. 2017) and contain analyzable quantities of toxins at these stages in natural populations (Bókony et al. 2016). We sampled tadpoles by dip netting at several locations within ponds and haphazardly selecting from among the captured specimens ten individuals per pond. We fixed tadpoles in $1 \mathrm{ml}$ absolute HPLC grade methanol, and stored samples at $-20^{\circ} \mathrm{C}$.

Bacterial community analysis based on terminal restriction fragment length polymorphism. We filtered $700 \mathrm{~mL}$ aliquots of each water sample through a $0.45 \mu \mathrm{m}$ pore-sized cellulose nitrate membrane filter (Millipore, Billerica, MA, USA). Environmental DNA was extracted from the filters using the PowerSoil® DNA Isolation Kit (MoBio Laboratories, Carlsbad, CA, USA) according to the manufacturer's instructions, with the exception that cell disruption was achieved by shaking at $25 \mathrm{~Hz}$ for 2 min using a Mixer Mill MM301 (Retsch, Haan, Germany).
For PCR amplification we used HEX-labelled 27F (5'-AGA GTT TGA TCM TGG CTC AG-3') and 534R (5'-ATT ACC GGG GCT GCT-3') 16S rDNA-specific primers (Lane 1991). The PCR mixture contained 2.5 U DreamTaq ${ }^{\mathrm{TM}}$ DNA Polymerase (Thermo Fisher Scientific, Waltham, MA, USA), $1 \times$ DreamTaq $^{\mathrm{TM}}$ Buffer (Thermo Fisher Scientific), $0.2 \mu \mathrm{L}$ of each dNTP, $0.3 \mu \mathrm{M}$ of each primer, $20 \mu \mathrm{g}$ BSA (Thermo Fisher Scientific), and $1 \mu \mathrm{L}$ of template DNA in a final volume of $50 \mu \mathrm{L}$. Thermal profile consisted of an initial denaturation at $98{ }^{\circ} \mathrm{C}$ for $5 \mathrm{~min}$, followed by 32 amplification cycles $\left(94{ }^{\circ} \mathrm{C}\right.$ for $30 \mathrm{~s}, 52^{\circ} \mathrm{C}$ for $30 \mathrm{~s}$ and $72^{\circ} \mathrm{C}$ for $30 \mathrm{~s}$ ), and a final extension step at $72{ }^{\circ} \mathrm{C}$ for $10 \mathrm{~min}$. Aliquots of the labelled PCR products $(13 \mu \mathrm{L})$ were digested in a final volume of $20 \mu \mathrm{L}$ with $1.5 \mathrm{U}$ restriction endonucleases AluI and Bsh1236I (Thermo Fisher Scientific), separately for $3 \mathrm{~h}$ at $37^{\circ} \mathrm{C}$. The purification of enzymatic digests and electrophoresis of labelled fragments were carried out as described previously (Sipos et al. 2007).

Analysis of bufadienolides. We homogenized tadpoles with a VWR VDI 12 blender and attached IKA S12N-7S dispersing tool. We dried samples under vacuum at $45{ }^{\circ} \mathrm{C}$ using a rotary evaporator (Büchi Rotavapor R-134), and measured dry mass to the nearest $0.1 \mathrm{mg}$ using an analytical balance (Sartorius Entris 224i-1S). We redissolved the dried samples in $1 \mathrm{ml}$ absolute HPLC grade methanol, which was aided by brief exposure to ultrasound in a bath sonicator (Tesla UC005AJ1). Finally, we filtered samples with $0.22 \mu \mathrm{m}$ pore sized FilterBio nylon syringe filters and stored them at $-20^{\circ} \mathrm{C}$ until further analysis.

We analyzed bufadienolide compounds using highperformance liquid chromatography coupled with diodearray detector and mass spectrometry (HPLC-DAD-MS) on 
a Shimadzu LC-MS 2020 instrument (Shimadzu, Kyoto, Japan) that consists of a binary gradient solvent pump, a vacuum degasser, a thermostated autosampler, a column oven, a diode array detector and a single-quadrupole mass analyzer with electrospray ionization (ESI-MS) We identified the chromatographic peaks as bufadienolides based on their UV spectrum (Hayes et al. 2009a) and by comparing their retention time and mass spectrum to commercially available standards of bufalin, bufotalin, resibufogenin, gamabufotalin, arenoand telocinobufagin (Biopurify Phytochemicals, Chengdu, China), cinobufagin (Chembest, Shanghai, China), cinobufotalin (Quality Phytochemicals, New Jersey, USA), digitoxigenin (Santa Cruz Biotechnology, Dallas, TX, USA) and marinobufotoxin (kindly provided by Prof. Rob Capon, Institute for Molecular Bioscience, University of Queensland, Australia). We also compared results to those obtained on a sample we took from an adult male common toad by gently massaging the parotoid glands. As UV spectra are more characteristic in adults (clean and concentrated) than homogenized tadpoles, this helps in detecting unidentified compounds (if molecular standards are absent) comparing retention time and $\mathrm{m} / \mathrm{z}$ values. Chromatographic separations were carried out at $35^{\circ} \mathrm{C}$ on a Kinetex C18 $2.6 \mu \mathrm{m}$ column $(100 \mathrm{~mm} \times$ $3 \mathrm{~mm}$ i.d. $)$ in series with a $\mathrm{C} 18$ guard column $(4 \mathrm{~mm} \times 3 \mathrm{~mm}$ i.d.) using $10 \mu \mathrm{L}$ injections. Eluent $\mathrm{A}$ was $5 \%$ aqueous acetonitrile with $0.05 \%$ formic acid and eluent $B$ was acetonitrile with $0.05 \%$ formic acid. The flow rate was $0.8 \mathrm{~mL} / \mathrm{min}$ and the gradient was as follows: $0-2 \mathrm{~min}, 10.5-21.1 \% \mathrm{~B} ; 2$ $15 \mathrm{~min}, 21.1-26.3 \% \mathrm{~B}$; $15-24 \mathrm{~min}, 26.3-47.4 \% \mathrm{~B}$; 24 $25 \mathrm{~min}, 47.4-100 \% \mathrm{~B} ; 25-30 \mathrm{~min} 100 \% \mathrm{~B} ; 30-31 \mathrm{~min}$ $100-10.5 \% \mathrm{~B} ; 31-35 \min 10.5 \% \mathrm{~B}$. ESI conditions were as follows: desolvation line (DL) temperature: $250{ }^{\circ} \mathrm{C}$; heat block temperature: $400{ }^{\circ} \mathrm{C}$; drying $\mathrm{N} 2$ gas flow: $15 \mathrm{~L} / \mathrm{min}$; nebulizer $\mathrm{N} 2$ gas flow: $1.5 \mathrm{~L} / \mathrm{min}$; positive ionization mode. Data was acquired and processed using the software LabSolutions 5.42v (Shimadzu Corp., Kyoto, Japan).

Statistical analyzes. To avoid redundancy by entering closely related predictor variables into statistical analyzes, we first checked for possible correlations between habitat characteristics using non-parametric correlations (Spearman's rho) and only used variables whose pairwise correlation coefficients did not exceed 0.5 . Consequently, we had to ignore water depth, shade, $\mathrm{pH}$ and conductivity (Table OR 1 in Electronic supplementary material 2).

TRFLP chromatograms were analyzed with the GeneMapper® Software v3.7 (Applied Biosystems, Foster City, CA, USA). Only TRFs longer than 50 bps were used. Further data processing was carried out according to an updated script of Abdo and colleagues (Abdo et al. 2006; the R script is available upon request). We applied the following parameters: noise filtration based on standard deviation (multiplier $=3$ ) of peak area, TRF alignment with 1 bp clustering threshold. The resulting alignment was compared to the raw chromatograms and corrected manually if necessary. For normalization the relative abundance of each detected TRFs within a given TRFLP profile was calculated. In order to get a more robust result, we combined the data matrix obtained using the AluI and Bsh1236I enzymes.

The bacterial community structure based on the TRFLP data was visualized with nonmetric multi-dimensional scaling (NMDS) with 3 dimensions (stress $=0.0997$ ) using the vegan package (Oksanen et al. 2016) in R (R Development Core Team 2016; http://www.r-project.org/). The 3D NMDS was preferred over the 2D NMDS because the former had a lower stress value and differed more significantly from simulated randomized data matrices generated using the 'oecosimu' function in the vegan package.

From three ponds we were only able to collect 5,4 , and 3 tadpoles, and during sample preparation we lost one sample each from 2 further ponds. This resulted in a total of 140 samples on bufadienolide content of tadpoles (Table 1). We described chemical defenses with two variables: we determined the number of bufadienolide compounds (NBC) and calculated total bufadienolide quantity (TBQ) for each animal. We assumed a compound to be present when its signal was at least three-times higher than random noise in the chromatogram (when the area below the curve was larger than 4000). Second, we estimated the quantity of each bufadienolide compound from the area values of chromatogram peaks based on the calibration curve of the bufotalin standard, and summed up these bufotalin-equivalent values to obtain an estimate of total bufadienolide quantity (TBQ) per individual. The use of the calibration curve of the bufotalin standard to obtain approximate estimates of bufadienolide quantities has been successfully used before in similar studies (Bókony et al. 2016; Hagman et al. 2009; Ujszegi et al. 2017). We analyzed NBC with cumulative link mixed modeling procedures (CLMM) with a logit link function and equidistant threshold using the ordinal Rpackage (Christensen 2015). We entered $\log _{10}$-transformed values of TBQ to enhance normality of model residuals and homogeneity of variances and used linear mixed modeling procedures (LMM). We performed model selection relying on Akaike's information criterion corrected for sample sizes (AICc).

Full models included pond ID as a random factor, and the following covariates as fixed factors: developmental stage of toad tadpoles; the three NMDS axes created from TRFLP data (NMDS 1, 2 and 3) describing the bacterial community of ponds, density of conspecific larvae, density of other amphibian larvae and density of predators (biotic factors), pond surface area and vegetation cover (abiotic pond parameters). As we were predominantly interested in effects of the bacterial community on toxin variables, we created the following models a priori: 1 . null model, containing only pond ID as a random factor; 2. pond ID + developmental stage of toad 
tadpoles; 3 . pond ID + developmental stage of toad tadpoles + NMDS axes describing bacterial community; 4 . pond ID + developmental stage of toad tadpoles + NMDS axes describing bacterial community + biotic factors; 5 . pond ID + developmental stage of toad tadpoles + NMDS axes describing bacterial community + abiotic pond parameters; 6 . pond ID + developmental stage of toad tadpoles + NMDS axes describing bacterial community + biotic factors + abiotic pond parameters. We used the maximum likelihood method for estimations and compared models using the MuMIn package (Barton 2017) in R. We entered $\log _{10}$-transformed values of pond surface, density of conspecific larvae and density of predators. We checked the homogeneity of variances using diagnostic plots. We calculated variance inflation factors (VIF) for each variable to detect multicollinearity, which was not found. Models were considered significantly different from each other in case of difference by more than four AICc values. In case of more than one best-supported model, effects were estimated using model averaged coefficients (MuMin package, conditional average matrix). We also compared models containing all the measured abiotic parameters (regardless of correlations between them) or using the mass corrected TBQ with the same methods described above, which results can be seen in Electronic supplementary material 2. We ran all analyses in R 3.4.0.

\section{Results}

In total, we identified 12 compounds as bufadienolides based on their UV spectra, but only one of these was found to be identical with one of the standards (marinobufotoxin). The number of bufadienolide compounds present in individual tadpoles ranged between 8 and 12 compounds. The frequency of occurrence of some compounds varied largely between ponds (i. e. compound 2, 3, marinobufotoxin, 5 and 10), whereas other compounds were consistently present in most sampled tadpoles in all ponds (Table 2).

The best-fitting model describing among-population variation in NBC (range of population mean NBC: 9.33-12 compounds / tadpole, see Table 2) included bacterial community structure, biotic parameters and developmental stage of toad tadpoles as explanatory variables. This model was clearly more supported by the data than the second best model or the null model $(\triangle \mathrm{AICc}=4.22$ and 5.13, respectively; Table OR 2a in Electronic supplementary material2). Further, the $95 \%$ confidence intervals computed for the parameter estimate of the NMDS 3 axis and for the density of conspecific larvae did not include zero (see Table OR 3a in Electronic supplementary material 2; Fig. 1), indicating that the number of bufadienolide compounds present in toad tadpoles covaried with some aspects of bacterial community structure, and that the number of compounds increased in parallel with an increasing density of conspecifics. Parameter estimate of the NMDS 2 was also relatively large, but its $95 \% \mathrm{CI}$ included zero, so that we consider its relationship with NBC to be non-significant (Table OR 3a in Electronic supplementary material 2; Fig. 1).

Total bufadienolide quantity varied widely among ponds (range of population mean TBQ: 1915-9239 ng / tadpole, see Table 2). The model containing bacterial community data and biotic factors with developmental stages as explanatory variables, followed by the full model containing all predictors were the best-supported models: however, they differed by 3.64 AICc values from each other, and more than eight AICc values from the third best model (Table OR $2 b$ in Electronic supplementary material 2). The $95 \%$ confidence intervals for the model-averaged parameter estimates of NMDS 1 axis and the density of conspecific larvae did not include zero, indicating that TBQ was related to bacterial community structure in the aquatic environment and was in a positive relationship with the density of conspecific larvae (Table OR 3b in Electronic supplementary material 2; Fig. 2). Model selection procedures including all measured pond parameters (regardless of correlations between them), and mass corrected TBQ values gave very similar results (Electronic supplementary material 2).

\section{Discussion}

Our results are the first to suggest that toxin content of tadpoles is related to the bacterial community structure of their environment. Both NBC and TBQ were correlated with one or two NMDS axes describing the bacterial community of larval habitats. This may be a cause-effect relationship, because bufadienolides can have antipathogenic and antiparasitic effects (Barnhart et al. 2017; Cunha Filho et al. 2005; Tempone et al. 2008), and Bufonid toads lack AMP-s (Conlon 2011; König et al. 2015), therefore the involvement of bufadienolides in skin-based immune-defense is probable, and their synthesis may be adjusted to the presence or absence of particular pathogens or specific members of bacterial communities. The presence of certain bacteria and changes in the natural microbiota can induce responses in chemical defenses (up- or down-regulation of AMP synthesis) in adult frogs (Mangoni et al. 2001; Miele et al. 1998; Simmaco et al. 1998). Nonetheless, the correlation between toxin content and individual NMDS axes does not inform us about which bacterial taxa are responsible for this relationship because NMDS axes describing bacterial community structure are derived from the visualization of the TRFLP data matrix for the sake of dimension reduction. Physical and chemical parameters were highly variable among habitats (Electronic supplementary material 1), contributing to a distinct bacterial community in each one of the studied ponds (Electronic 


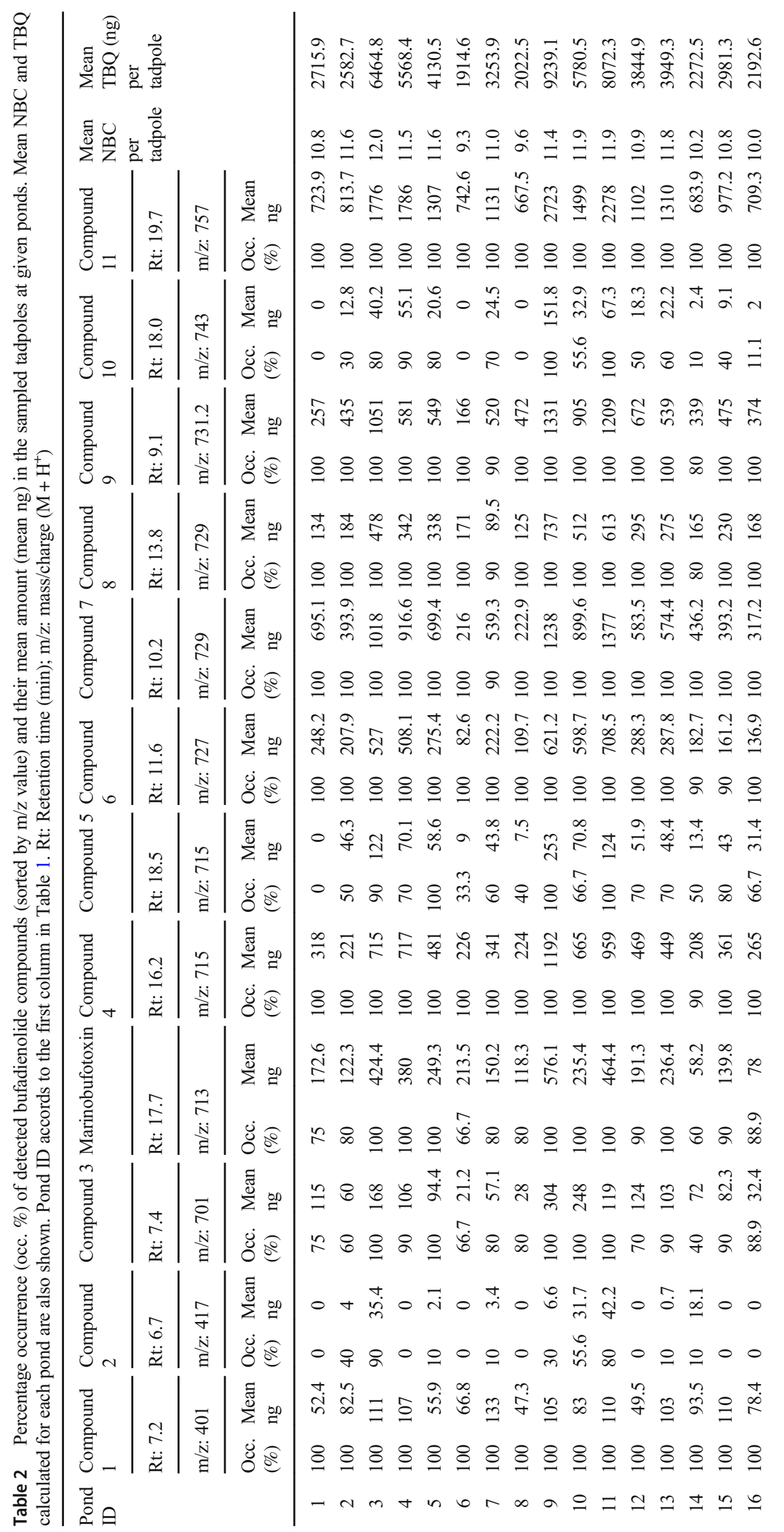




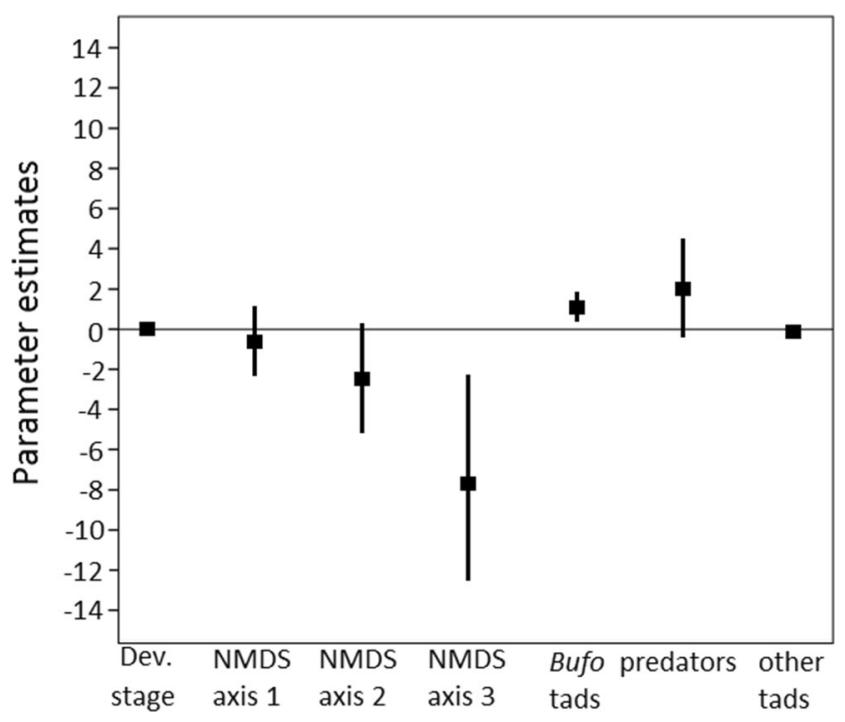

Fig. 1 Parameter estimates (black squares) for explanatory variables obtained from the best fitting model describing the pattern of number of bufadienolide compounds (NBC) found in common toad tadpoles in the 16 studied ponds. Vertical lines depict $95 \%$ confidence intervals. Abbreviations: Dev. Stage developmental stage, NMDS nonmetric multi-dimensional scaling, tads tadpoles

supplementary material 3, Fig. 3). Therefore, local adaptation to the local microbiota at the level of chemical defenses may contribute to the observed variance in toxicity of common toad tadpoles. Although we did not find a direct effect of abiotic environmental factors on toxin content, these factors can also influence skin associated chemical defenses (Krynak et al. 2015, 2016), thus we cannot completely exclude the possibility that the relationship between bacterial community structure and toxin content

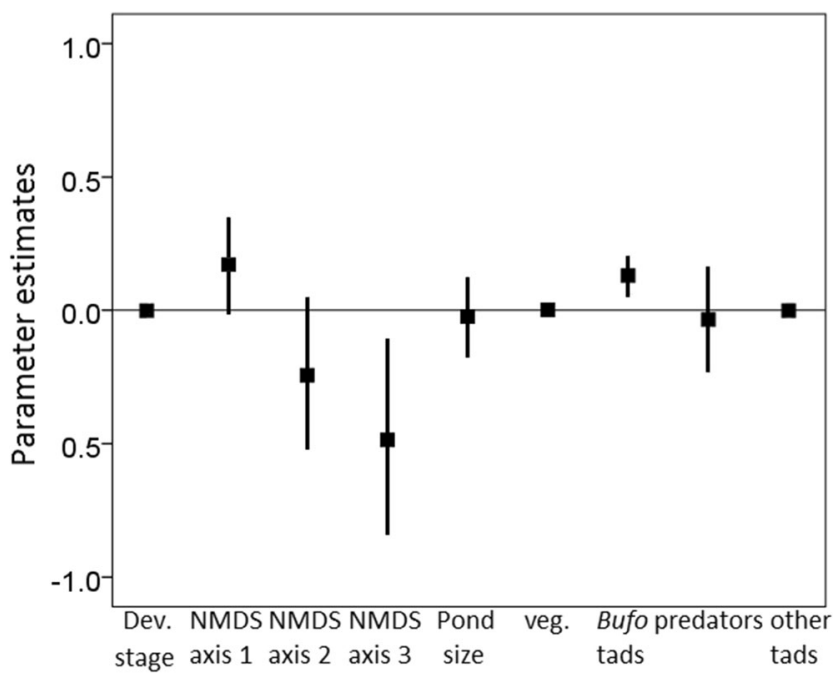

Fig. 2 Parameter estimates (black squares) for explanatory variables obtained from model averaging procedures describing the pattern of total bufadienolide quantity (TBQ) found in common toad tadpoles in the 16 studied ponds. Vertical lines depict $95 \%$ confidence intervals. Abbreviations: Dev. Stage developmental stage, NMDS nonmetric multi-dimensional scaling, veg. macro-vegetation cover, tads tadpoles resulted from correlations with a non-measured background variable. For example, anthropogenic pollution can influence both toxin content (Bókony et al. 2019; Zhou et al. 2019) and microbial community (Aguinaga et al. 2018; Widenfalk et al. 2008). Finally, some bacteria inhabiting the skin of toads are able to transform bufadienolide compounds (Hayes et al. 2009b; Kamalakkannan et al. 2017), which may have contributed to the observed relationship between NBC and bacterial community structure in our study. This mechanism, however, is unlikely to explain the observed patterns in TBQ.

The positive relationship between both NBC and TBQ and the density of conspecific tadpoles is in line with results of a previous correlative study (Bókony et al. 2016) that was conducted one year earlier on a partly overlapping suite of ponds (10 ponds overlapped between the former and the current study). The similarity between results suggests that the observed pattern may be generalized over time and populations, at least within the study area, and suggests that the synthesis of bufadienolides is boosted in response to elevated conspecific density. Experimental studies confirmed these results (Bókony et al. 2018) in our study species. Similarly, AMP synthesis in leopard frogs (Lithobates pipiens) was increased after metamorphosis in individuals that had faced strong competition during the larval stage (Groner et al. 2014). These changes in chemical defenses may be interpreted as adaptive plasticity manifesting in the form of responsive immune defense, because the chance of pathogen transmission grows if the density of similar hosts increases (Briggs et al. 2010), which is likely to render enhanced investment into immunedefenses beneficial at high conspecific densities. Presence of predators did not influence skin toxin production, most probably because fishes, which excite the strongest antipredatory responses in chemical defenses (Hettyey et al. 2019), are absent from the sampled ponds, and because the weaker effects of invertebrate predators were masked by those of widely varying densities of conspecific tadpoles.

We observed large variation in tadpoles' developmental stages among the studied ponds (Table 1). Even though previous laboratory-based experiments showed that toxin quantity of B. bufo tadpoles can vary according to developmental stage (Ujszegi et al. 2017; Üveges et al. 2017), we could not avoid such differences among ponds, because natural habitats inherently vary in environmental factors affecting tadpole development (McDiarmid and Altig 1999). However, this variation in developmental stage did not have an effect either on NBC or on TBQ in the present study (Figs. 1 and 2) and the models containing only developmental stage were weakly supported (Table OR 2 in Electronic supplementary material 2). This was likely caused by the fact that the majority of the analyzed tadpoles reached, or passed the middle of their larval development, when toxin production already reached a plateau and does not change much until metamorphosis (Ujszegi et al. 2017; Üveges et al. 2017). 
Fig. 3 Bacterial community structure in the studied ponds visualized from results of TRFLP. Height of each rectangle in the columns refers to the abundance of the given fragment in the sample. Isochromatic rectangles close to each other between the samples indicate the same fragments. Note that colour palette is vertically repeating, because of the high number of fragments. Numbers are in accordance with the Pond ID column in Table 1

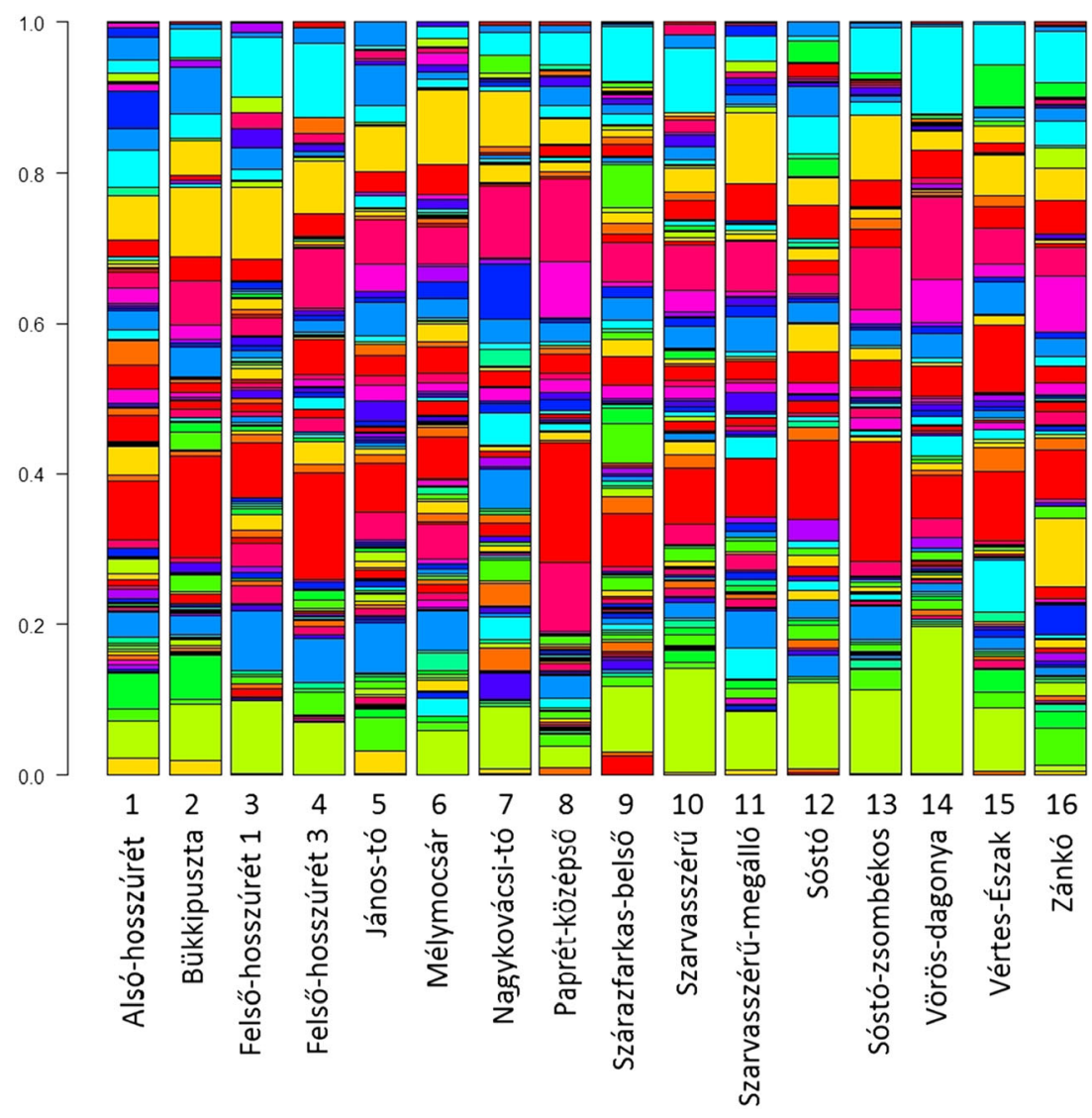

In summary, by investigating correlations between bacterial community structure of aquatic habitats and skin-based chemical defenses of toad tadpoles we demonstrated that chemical defenses of tadpoles are related to the bacterial community structure of their natural aquatic habitats. Furthermore, in accordance with previous findings (Bókony et al. 2016), the toxin content of larval toads was also related to the density of conspecific tadpoles. Revealing the most important bacterial groups that are related to temporal or spatial variation in skinborne chemical defenses of tadpoles, and perhaps induce these changes, would be an important step towards understanding the processes shaping interactions between environmental microbiota and amphibian chemical defenses.

Acknowledgments We thank M. Szederkényi, B. Üveges, T. Sendula, J. Hartdégen, Zs. Pillió and Zs. Mikó for assistance during field sampling, V. Bókony, B. Üveges and A. Borsodi for help in statistical and microbial analyses, and the Pilisi Parkerdö Zrt. for allowing us to use their roads. The Közép-Duna-Völgyi KTVF issued the permission to conduct the study (KTF:2771-3/2015 and KTF:2771-4/2015) and the Ethical Commission of the ATK NÖVI approved the investigation in accordance with Good Scientific Practice guidelines and national legislation. Research was supported by the Lendület Programme of the Hungarian Academy of Sciences (MTA, LP2012-24/2012) and an FP7 Marie Curie Career Integration Grant (PCIG13-GA-2013-631722), AH was supported by a Bolyai+ Scholarship of the New National Excellence Programme of the Ministry of Human Capacities, Hungary (ÚNKP, EMMI), and the National Research, Development and Innovation Office (NKFIH) of Hungary (grant no. K-124375). The authors have no conflict of interest to declare.
Funding Information Open access funding provided by Centre for Agricultural Research.

Open Access This article is licensed under a Creative Commons Attribution 4.0 International License, which permits use, sharing, adaptation, distribution and reproduction in any medium or format, as long as you give appropriate credit to the original author(s) and the source, provide a link to the Creative Commons licence, and indicate if changes were made. The images or other third party material in this article are included in the article's Creative Commons licence, unless indicated otherwise in a credit line to the material. If material is not included in the article's Creative Commons licence and your intended use is not permitted by statutory regulation or exceeds the permitted use, you will need to obtain permission directly from the copyright holder. To view a copy of this licence, visit http://creativecommons.org/licenses/by/4.0/.

\section{References}

Abdo Z, Schüette UME, Bent SJ et al (2006) Statistical methods for characterizing diversity of microbial communities by analysis of terminal restriction fragment length polymorphisms of $16 \mathrm{~S}$ rRNA genes. Environ Microbiol 8:929-938

Aguinaga OE, McMahon A, White KN, Dean AP, Pittman JK (2018) Microbial community shifts in response to acid mine drainage pollution within a natural wetland ecosystem. Front Microbiol 9:1445. https://doi.org/10.3389/fmicb.2018.01445

Barnhart K, Forman ME, Umile TP, Kueneman J, McKenzie V, Salinas I, Minbiole KPC, Woodhams DC (2017) Identification of 
bufadienolides from the boreal toad, Anaxyrus boreas, active against a fungal pathogen. Microb Ecol 74:990-1000. https://doi.org/10. 1007/s00248-017-0997-8

Bartoń K (2017) MuMIn: Multi-Model Inference. R Package http:// CRAN.R-project.org/package=MuMIn; Accessed 1 February 2019

Bókony V, Móricz ÁM, Tóth Z, Gál Z, Kurali A, Mikó Z, Pásztor K, Szederkényi M, Tóth Z, Ujszegi J, Üveges B, Krüzselyi D, Capon RJ, Hoi H, Hettyey A (2016) Variation in chemical defense among natural populations of common toad, Bufo bufo, tadpoles: the role of environmental factors. J Chem Ecol 42:329-338. https://doi.org/10. 1007/s10886-016-0690-2

Bókony V, Üveges B, Móricz ÁM, Hettyey A (2018) Competition induces increased toxin production in toad larvae without allelopathic effects on heterospecific tadpoles. Funct Ecol 32:667-675. https:// doi.org/10.1111/1365-2435.12994

Bókony V, Üveges B, Verebélyi V, Ujhegyi N, Móricz ÁM (2019) Toads phenotypically adjust their chemical defences to anthropogenic habitat change. Sci Rep 9:3163. https://doi.org/10.1038/s41598-019-39587-3

Briggs CJ, Knapp RA, Vredenburg VT (2010) Enzootic and epizootic dynamics of the chytrid fungal pathogen of amphibians. Proc Natl Acad Sci U S A 107:9695-9700. https://doi.org/10.1073/pnas. 0912886107

Brodie DEI (2009) Toxins and venoms. Curr Biol 19:931-935. https:// doi.org/10.1016/B978-0-12-415813-9.00014-3

Christensen RHB (2015) A tutorial on fitting Cumulative Link Mixed Models with clmm2 from the ordinal package. Tutorial for the $\mathrm{R}$ Package ordinal https://cran.r-project.org/web/packages/ordinal/ Accessed 1 February 2019

Conlon JM (2011) The contribution of skin antimicrobial peptides to the system of innate immunity in anurans. Cell Tissue Res 343:201212. https://doi.org/10.1007/s00441-010-1014-4

Cunha Filho GA, Schwartz CA, Resck IS, Murta MM, Lemos SS, Castro MS, Kyaw C, Pires OR Jr, Leite JRS, Bloch C Jr, Schwartz EF (2005) Antimicrobial activity of the bufadienolides marinobufagin and telocinobufagin isolated as major components from skin secretion of the toad Bufo rubescens. Toxicon 45:777-782. https://doi. org/10.1016/j.toxicon.2005.01.017

Daly JW (1995) The chemistry of poisons in amphibian skin. Proc Natl Acad Sci U S A 92:9-13. https://doi.org/10.1073/pnas.92.1.9

Denton J, Beebee TJC (1991) Palatibility of anuran eggs and embryos. Amphibia-Reptilia 12:111-114

DeWitt TJ, Scheiner SM (2004) Phenotypic variation from single genotypes: a primer. In: TJ DW, Scheiner SM (eds) Phenotypic plasticity: functional and conceptual approaches. Oxford University Press, New York, pp 1-9

Groner ML, Rollins-Smith LA, Reinert LK et al (2014) Interactive effects of competition and predator cues on immune responses of leopard frogs at metamorphosis. J Exp Biol 217:351-358. https://doi.org/10. 1242/jeb.091611

Hagman M, Hayes RA, Capon RJ, Shine R (2009) Alarm cues experienced by cane toad tadpoles affect post-metamorphic morphology and chemical defences. Funct Ecol 23:126-132. https://doi.org/10. 1111/j.1365-2435.2008.01470.x

Hague MT, Avila LA, Hanifin CT et al (2016) Toxicity and population structure of the rough-skinned newt (Taricha granulosa) outside the range of an arms race with resistant predators. Ecol Evol 6:2714 2724. https://doi.org/10.1002/ece3.2068

Hantak MM, Paluh DJ, Saporito RA (2016) Bufadienolide and alkaloidbased chemical defences in two different species of neotropical anurans are equally effective against the same arthropod predators. J Trop Ecol 32:165-169. https://doi.org/10.1017/ S0266467416000055

Harvell CD (1990) The ecology and evolution of inducible defenses. Q Rev Biol 65:323-340. https://doi.org/10.1086/416841

Hayes RA, Crossland MR, Hagman M, Capon RJ, Shine R (2009a) Ontogenetic variation in the chemical defenses of cane toads (Bufo marinus): toxin profiles and effects on predators. J Chem Ecol 35: 391-399. https://doi.org/10.1007/s10886-009-9608-6

Hayes RA, Piggott AM, Dalle K, Capon RJ (2009b) Microbial biotransformation as a source of chemical diversity in cane toad steroid toxins. Bioorganic Med Chem Lett 19:1790-1792. https://doi.org/ 10.1016/j.bmcl.2009.01.064

Hettyey A, Tóth Z, Van Buskirk J (2014) Inducible chemical defences in animals. Oikos 23:1025-1028. https://doi.org/10.1111/OIK.01338

Hettyey A, Üveges B, Móricz ÁM, Drahos L, Capon RJ, van Buskirk J, Tóth Z, Bókony V (2019) Predator-induced changes in the chemical defence of a vertebrate. J Anim Ecol 88:1925-1935. https://doi.org/ $10.1111 / 1365-2656.13083$

Kamalakkannan V, Salim AA, Capon RJ (2017) Microbiome-mediated biotransformation of cane toad bufagenins. J Nat Prod 80:20122017. https://doi.org/10.1021/acs.jnatprod.7b00134

König E, Bininda-Emonds ORP, Shaw C (2015) The diversity and evolution of anuran skin peptides. Peptides 63:96-117. https://doi.org/ 10.1016/j.peptides.2014.11.003

Krenn L, Kopp B (1998) Bufadienolides from animal and plant sources. Phytochemistry 48:1-29. https://doi.org/10.1016/S0031-9422(97) 00426-3

Kruse KC, Stone BM (1984) Largemouth bass (Micropterus salmoides) learn to avoid feeding on toad (Bufo) tadpoles. Anim Behav 32: 1035-1039

Krynak KL, Burke DJ, Benard MF (2015) Larval environment alters amphibian immune defenses differentially across life stages and populations. PLoS One 10:1-22. https://doi.org/10.1371/journal. pone. 0130383

Krynak KL, Burke DJ, Benard MF (2016) Landscape and water characteristics correlate with immune defense traits across Blanchard's cricket frog (Acris blanchardi) populations. Biol Conserv 193: 153-167. https://doi.org/10.1016/j.biocon.2015.11.019

Lane DJ (1991) 16S/23S rRNA sequencing. In: Stackebrandt E, Goodfellow M (eds) Nucleic acids techniques in bacterial systematics. Wiley, NewYork, pp 115-175

Mangoni ML, Miele R, Renda TG, Barra D, Simmaco M (2001) The synthesis of antimicrobial peptides in the skin of Rana esculenta is stimulated by microorganisms. FASEB J 15:1431-1432

McCall AC, Fordyce JA (2010) Can optimal defence theory be used to predict the distribution of plant chemical defences? J Ecol 98:985992. https://doi.org/10.1111/j.1365-2745.2010.01693.x

McDiarmid RW, Altig R (1999) Tadpoles. the biology af anuran larvae. The University of Chicago Press, Chicago

Mebs D (2001) Toxicity in animals. Trends in evolution? Toxicon 39:8796. https://doi.org/10.1016/S0041-0101(00)00155-0

De Medeiros DSS, Rego TB, dos Santos APDA et al (2019) Biochemical and biological profile of parotoid secretion of the Amazonian Rhinella marina (Anura: Bufonidae). Biomed Res Int 2019: 2492315-2492315. https://doi.org/10.1155/2019/2492315

Miele R, Ponti D, Boman HG, Barra D, Simmaco M (1998) Molecular cloning of a bombinin gene from Bombina orientalis: detection of NF-KB and NF-IL6 binding sites in its promoter. FEBS Lett 431: 23-28. https://doi.org/10.1016/S0014-5793(98)00718-2

Nei M, Maruyama T, Chakraborty R (1975) The Bottleneck effect and genetic variability in populations. Evolution 29:1-10

Oksanen J, Blanchet FG, Friendly M, et al (2016) Vegan: Community Ecology Package. R Package https://cran.r-project.org/web/ packages/vegan/ Accessed 26 January 2017

Peterson JA, Blaustein AR (1991) Unpalatability in anuran larvae as a defense against natural salamander predators. Ethol Ecol Evol 3:6372. https://doi.org/10.1080/08927014.1991.9525389

Rebollar EA, Hughey MC, Medina D, Harris RN, Ibáñez R, Belden LK (2016) Skin bacterial diversity of Panamanian frogs is associated with host susceptibility and presence of Batrachochytrium dendrobatidis. ISME J 10:1682-1695. https://doi.org/10.1038/ ismej.2015.234 
Shine R (2010) The ecological impact of invasive cane toads (Bufo marinus) in Australia. Q Rev Biol 85:253-291

Simmaco M, Mangoni ML, Boman A, Barra D, Boman HG (1998) Experimental infections of Rana esculenta with Aeromonas hydrophila: a molecular mechanism for the control of the normal flora. Scand J Immunol 48:357-363. https://doi.org/10.1046/j.13653083.1998.00407.x

Sipos R, Székely AJ, Palatinszky M et al (2007) Effect of primer mismatch, annealing temperature and PCR cycle number on 16S rRNA gene-targetting bacterial community analysis. FEMS Microbiol Ecol 60:341-350

Steyn PS, van Heerden FR (1998) Bufadienolides of plant and animal origin. Nat Prod Rep 15:397-413. https://doi.org/10.1039/a815397y

Tempone AG, Pimenta DC, Lebrun I, Sartorelli P, Taniwaki NN, de Andrade HF Jr, Antoniazzi MM, Jared C (2008) Antileishmanial and antitrypanosomal activity of bufadienolides isolated from the toad Rhinella jimi parotoid macrogland secretion. Toxicon 52:1321. https://doi.org/10.1016/j.toxicon.2008.05.008

Toledo RC, Jared C (1995) Cutaneous granular glands and amphibian venoms. Comp Biochem Physiol - Part A Physiol 111:1-29. https:// doi.org/10.1016/0300-9629(95)98515-I

Tollrian R, Harvell D (1999) The ecology and evolution of inducible defences. Princeton University Press, Princeton

Ujszegi J, Móricz ÁM, Krüzselyi D, Hettyey A (2017) Skin toxin production of toads changes during early ontogeny but is not adjusted to the microbiota of the aquatic environment. Evol Ecol 31:925-936. https://doi.org/10.1007/s10682-017-9920-5
Üveges B, Fera G, Móricz ÁM, Krüzselyi D, Bókony V, Hettyey A (2017) Age- and environment-dependent changes in chemical defences of larval and post-metamorphic toads. BMC Evol Biol 17: 137. https://doi.org/10.1186/s12862-017-0956-5

Vági B, Kovács T, Băncilă R et al (2013) A landscape-level study on the breeding site characteristics of ten amphibian species in Central Europe. Amphib Reptil 34:63-73. https://doi.org/10.1163/ 15685381-00002869

Vartoukian SR, Palmer RM, Wade WG (2010) Strategies for culture of "unculturable" bacteria. FEMS Microbiol Lett 309:1-7. https://doi. org/10.1111/j.1574-6968.2010.02000.x

Walke JB, Becker MH, Loftus SC et al (2014) Amphibian skin may select for rare environmental microbes. ISME J 8:2207-2217. https://doi. org/10.1038/ismej.2014.77

West-Eberhard MJ (1989) Phenotypic plasticity and the origins of diversity. Annu Rev Ecol Syst 20:249-278

Widenfalk A, Bertilsson S, Sundh I, Goedkoop W (2008) Effects of pesticides on community composition and activity of sediment microbes - responses at various levels of microbial community organization. Environ Pollut 152:576-584. https://doi.org/10.1016/j. envpol.2007.07.003

Zhou J, Zhao H, Chen L, Xing X, Lv T, Yang X, Wu Q, Duan J, Ma H (2019) Effect of exposure to deltamethrin on the bufadienolide profiles in Bufo bufo gargarizans venom determined by ultraperformance liquid chromatography-triple quadrupole mass spectrometry. RSC Adv 9:1208-1213. https://doi.org/10.1039/ C8RA07871H 